\title{
Front Matter: Volume 6708
}

, "Front Matter: Volume 6708," Proc. SPIE 6708, Atmospheric Optics: Models, Measurements, and Target-in-the-Loop Propagation, 670801 (30 October 2007); doi: 10.1117/12.774044

SPIE Event: Optical Engineering + Applications, 2007, San Diego, California, United SPIE. States 


\section{PROCEEDINGS OF SPIE}

\section{Atmospheric Optics: Models, Measurements, and Target-in-the-Loop Propagation}

Stephen M. Hammel

Alexander M. J. van Eijk

Michael T. Valley

Mikhail A. Vorontsov

Editors

27-28 August 2007

San Diego, California, USA

Sponsored and Published by

SPIE

Volume 6708 
The papers included in this volume were part of the technical conference cited on the cover and title page. Papers were selected and subject to review by the editors and conference program committee. Some conference presentations may not be available for publication. The papers published in these proceedings reflect the work and thoughts of the authors and are published herein as submitted. The publisher is not responsible for the validity of the information or for any outcomes resulting from reliance thereon.

Please use the following format to cite material from this book:

Author(s), "Title of Paper," in Atmospheric Optics: Models, Measurements, and Target-in-the-Loop Propagation, edited by Stephen M. Hammel, Alexander M. J. van Eijk, Michael T. Valley, Mikhail A. Vorontsov, Proceedings of SPIE Vol. 6708 (SPIE, Bellingham, WA, 2007) Article CID Number.

ISSN 0277-786X

ISBN 9780819468567

Published by

SPIE

P.O. Box 10, Bellingham, Washington $98227-0010$ USA

Telephone +1 3606763290 (Pacific Time) · Fax +1 3606471445

SPIE.org

Copyright (c) 2007, Society of Photo-Optical Instrumentation Engineers

Copying of material in this book for internal or personal use, or for the internal or personal use of specific clients, beyond the fair use provisions granted by the U.S. Copyright Law is authorized by SPIE subject to payment of copying fees. The Transactional Reporting Service base fee for this volume is $\$ 18.00$ per article (or portion thereof), which should be paid directly to the Copyright Clearance Center (CCC), 222 Rosewood Drive, Danvers, MA 01923. Payment may also be made electronically through CCC Online at copyright.com. Other copying for republication, resale, advertising or promotion, or any form of systematic or multiple reproduction of any material in this book is prohibited except with permission in writing from the publisher. The CCC fee code is $0277-786 \mathrm{X} / 07 / \$ 18.00$.

Printed in the United States of America.

Publication of record for individual papers is online in the SPIE Digital Library.

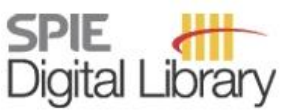

SPIEDigitalLibrary.org

Paper Numbering: Proceedings of SPIE follow an e-First publication model, with papers published first online and then in print and on CD-ROM. Papers are published as they are submitted and meet publication criteria. A unique, consistent, permanent citation identifier (CID) number is assigned to each article at the time of the first publication. Utilization of CIDs allows articles to be fully citable as soon they are published online, and connects the same identifier to all online, print, and electronic versions of the publication. SPIE uses a six-digit CID article numbering system in which:

- The first four digits correspond to the SPIE volume number.

- The last two digits indicate publication order within the volume using a Base 36 numbering system employing both numerals and letters. These two-number sets start with $00,01,02,03,04,05$, 06, 07, 08, 09, OA, OB ... 0Z, followed by 10-1Z, 20-2Z, etc.

The CID number appears on each page of the manuscript. The complete citation is used on the first page, and an abbreviated version on subsequent pages. Numbers in the index correspond to the last two digits of the six-digit CID number. 


\section{Contents}

vii Conference Committee

\section{SESSION 1 TURBULENCE MEASUREMENT AND MODELING}

670802 Analysis of free-space laser signal intensity over a $2.33 \mathrm{~km}$ optical path [6708-01]

A. Tunick, Army Research Lab. (USA)

670803 Free space optical system performance for laser beam propagation through non Kolmogorov turbulence for uplink and downlink paths [6708-02]

I. Toselli, Politecnico di Torino (Italy); L. C. Andrews, Univ. of Central Florida (USA);

R. L. Phillips, Univ. of Central Florida, Florida Space Institute (USA); V. Ferrero, Politecnico di Torino (Italy)

670804 Turbulence effects on laser propagation in a marine environment [6708-04]

S. Hammel, SPAWAR Systems Ctr. (USA)

670806 The Lévy fractional Brownian motion family as a new paradigm in the modeling of turbulent wave-front phase [6708-06]

D. G. Pérez, Pontificia Univ. Católica de Valparaíso (Chile); L. Zunino, M. Garavaglia, Ctr. de Investigaciones Ópticas (Argentina) and Univ. Nacional de La Plata (Argentina)

670807 Improving bulk $\mathrm{C}_{\mathrm{n}^{2}}$ models for over-ocean applications through new determinations of the dimensionless temperature structure parameter [6708-07]

P. A. Frederickson, Naval Postgraduate School (USA); S. Hammel, D. Tsintikidis, Space and Naval Warfare Systems Ctr. (USA)

670808 Coherent illumination for wavefront sensing and imaging through turbulence [6708-08] M.-T. Velluet, V. Michau, T. Fusco, J.-M. Conan, Office National d'Etudes et de Recherches Aérospatiales (France)

670809 Turbulence analysis of maritime horizontal laser propagation: experimental analysis and wave-optics simulation [6708-09]

B. P. Venet, MZA Associates Corp. (USA)

\section{SESSION 2 TURBULENCE COMPENSATION AND TIL MITIGATION}

$67080 \mathrm{~A}$ Turbulence effect mitigation using adaptive optics post-processing of holographically recorded short-exposure images [6708-10]

M. A. Vorontsov, Univ. of Maryland, College Park (USA) and Army Research Lab. (USA);

M. Aubailly, Univ. of Maryland, College Park (USA); R. Dou, New Mexico State Univ. (USA) 
$6708 \mathrm{OB}$ Integrated multi-dithering controller for adaptive optics [6708-11]

D. N. Loizos, Johns Hopkins Univ. (USA); L. Liu, Univ. of Maryland, College Park (USA); P. P. Sotiriadis, Johns Hopkins Univ. (USA); G. Cauwenberghs, Univ. of California, San Diego (USA); M. A. Vorontsov, Univ. of Maryland, College Park (USA) and Army Research Lab. (USA)

6708 OC Adaptive compensation over a $2.33 \mathrm{~km}$ propagation path with retro reflectors under strong scintillation conditions [6708-12]

E. Polnau, Univ. of Maryland, College Park (USA); M. A. Vorontsov, Univ. of Maryland, College Park (USA) and Army Research Lab. (USA); G. Carhart, Army Research Lab. (USA); T. Weyrauch, Univ. of Maryland, College Park (USA); L. A. Beresnev, Army Research Lab. (USA)

6708 OD Coherent combining of multiple beams with multi-dithering technique: $100 \mathrm{KHz}$ closedloop compensation demonstration [6708-13]

L. Liu, Univ. of Maryland, College Park (USA); D. N. Loizos, Johns Hopkins Univ. (USA);

M. A. Vorontsov, Univ. of Maryland, College Park (USA) and Army Research Lab. (USA);

P. P. Sotiriadis, Johns Hopkins Univ. (USA); G. Cauwenberghs, University of California, San Diego (USA)

6708 OE Anisoplanatic imaging through atmospheric turbulence: brightness function approach [6708-14]

S. L. Lachinova, Univ. of Maryland, College Park (USA); M. A. Vorontsov, Univ. of Maryland, College Park (USA) and Army Research Lab. (USA); V. V. Dudorov, Univ. of Maryland, College Park (USA) and Institute of Atmospheric Optics (Russia); V. V. Kolosov, Institute of Atmospheric Optics (Russia); M. T. Valley, Sandia National Labs. (USA)

\section{SESSION 3 TIL PROPAGATION AND TRACKING I}

6708 OF Uncooperative target-in-the-loop performance with backscattered speckle-field effects [6708-15]

J. E. Kansky, D. V. Murphy, MIT Lincoln Lab. (USA)

6708 OG The BEFWM system for detection and phase conjugation of a weak laser beam [6708-16] A. Khizhnyak, V. Markov, MetroLaser, Inc. (USA)

$6708 \mathrm{OH} \quad$ TIL system with nonlinear phase conjugation [6708-17]

A. Khizhnyak, V. Markov, MetroLaser, Inc. (USA)

\section{SESSION 4 TIL PROPAGATION AND TRACKING II}

6708 Ol Laboratory demonstration of wavefront-based stochastic parallel gradient descent adaptive optics system [6708-18] M. S. Belen'kii, Trex Enterprises Corp. (USA); J. Barchers, E. Berg, Science Applications International Corp. (USA); D. Bruns, Trex Enterprises Corp. (USA); D. Fung, R. Gallant, C. Kirk, Science Applications International Corp. (USA); H. Runyeon, V. Rye, Trex Enterprises Corp. (USA); J. Voass, Pipeline Processing Co. (USA) 
6708 0J Application of stereo laser tracking methods for quantifying flight dynamics [6708-19] H. W. Schreier, Correlated Solutions, Inc. (USA); T. J. Miller, M. T. Valley, T. L. Brown, Sandia National Labs. (USA)

6708 OK Adaptive phase-locked fiber array with wavefront phase tip-tilt compensation using piezoelectric fiber positioners [6708-20]

L. Liu, Univ. of Maryland, College Park (USA); M. A. Vorontsov, Univ. of Maryland, College

Park (USA) and Army Research Lab. (USA); E. Polnau, T. Weyrauch, Univ. of Maryland,

College Park (USA); L. A. Beresnev, Army Research Lab. (USA)

\section{SESSION 5 AEROSOL EXTINCTION: MODELING AND MEASUREMENT}

$6708 \mathrm{OL}$ The use of multi-band transmission data collected at Scripps pier in November 2006 for the investigation of aerosol characteristics [6708-21]

A. N. de Jong, A. M. J. van Eijk, P. J. Fritz, L. H. Cohen, M. M. Moerman, TNO Defence, Security and Safety (Netherlands)

$67080 \mathrm{~N} \quad$ Sea spray aerosol and wave energy dissipation in the surf zone [6708-23]

M. J. Francius, TNO Defence, Security and Safety (Netherlands); J. Piazolla, P. Forget,

O. Le Calve, Southern Univ. of Toulon-Var (France); J. Kusmierczyk-Michulec, TNO Defence, Security and Safety (Netherlands)

670800 Can we predict aerosol extinction in a coastal environment? [6708-24]

D. Tsintikidis, D. Kichura, S. Hammel, Atmospheric Propagation Branch, SSC, San Diego (USA)

6708 OP Ångström coefficient as a tracer of the continental aerosols [6708-25]

J. Kusmierczyk-Michulec, A. M. J. van Eijk, TNO Defence, Security and Safety (Netherlands)

$67080 Q$ Satellite retrieved aerosol properties for battlespace characterization and sensor performance [6708-26]

R. M. Schoemaker, TNO Defence, Security and Safety (Netherlands)

\section{SESSION $6 \quad$ NOVEL METHODS AND DESIGNS}

6708 OR Adaptive optical antennas: design and evaluation [6708-27]

T. Weyrauch, Univ. of Maryland, College Park (USA); M. A. Vorontsov, Univ. of Maryland, College Park (USA) and Army Research Lab. (USA); G. W. Carhart, Army Research Lab. (USA); G. V. Simonova, Institute for Monitoring of Climatic and Ecological Systems (Russia) and Technical Research Institute (USA); L. A. Beresnev, Army Research Lab. (USA);

E. E. Polnau, Univ. of Maryland, College Park (USA)

6708 OS Wavefront correctors based on semi-passive bimorph elements for adaptive optics applications: new designs [6708-28]

L. A. Beresnev, Army Research Lab. (USA)

6708 OU Finding the range to a distant object near the sea surface [6708-30]

M. A. C. Degache, TNO Defence, Security and Safety (Netherlands); S. Hammel, Space and Naval Warfare Systems Ctr., San Diego (USA) 
$6708 \mathrm{OV}$ Optical beam tracking based on nonlinear lens mechanism [6708-31]

A. S. Koujelev, A. E. Dudelzak, Canadian Space Agency (Canada)

6708 0X Intensity and polarization characteristics of the light scattered by the ice crystals of cirrus clouds with preferred orientations [6708-33]

A. V. Burnashov, A. Feldshtein, E. Sibiryakova, D. Dzhurmii, Institute of Atmospheric Optics (Russia)

6708 OY Picosecond eye-safe Raman laser for advanced ranging and tracking [6708-34]

O. V. Kulagin, N. F. Andreev, A. M. Sergeev, Institute of Applied Physics (Russia); M. Valley, Sandia National Labs. (USA)

Author Index 


\title{
Conference Committee
}

\author{
Conference Chairs \\ Stephen M. Hammel, Space and Naval Warfare Systems Center, San \\ Diego (USA) \\ Alexander M. J. van Eijk, TNO Defence, Security and Safety \\ (Netherlands) \\ Michael T. Valley, Sandia National Laboratories (USA) \\ Mikhail A. Vorontsov, Army Research Laboratory (USA) \\ Program Committee \\ Gail P. Anderson, Air Force Research Laboratory (USA) \\ Matthew M. Bold, Defense Strategies and Systems, Inc. (USA) \\ Frank D. Eaton, Air Force Research Laboratory (USA) \\ Charles Higgs, MIT Lincoln Laboratory (USA) \\ Vladimir B. Markov, MetroLaser, Inc. (USA) \\ Vincent Michau, ONERA (France) \\ Jennifer C. Ricklin, Defense Advanced Research Projects Agency \\ (USA) \\ James F. Riker, Air Force Research Laboratory (USA) \\ Michael C. Roggemann, Michigan Technological University (USA) \\ Don D. Seeley, High Energy Laser Joint Technology Office (USA) \\ Alexander M. Sergeev, Institute of Applied Physics (Russia) \\ Janet E. Shields, University of California, San Diego (USA) \\ Thomas Weyrauch, University of Maryland, College Park (USA)
}

Session Chairs

1 Turbulence Measurement and Modeling

Mikhail A. Vorontsov, Army Research Laboratory (USA)

2 Turbulence Compensation and TIL Mitigation

Michael T. Valley, Sandia National Laboratories (USA)

3 TIL Propagation and Tracking I

Alexander M. J. van Eijk, TNO Defence, Security and Safety

(Netherlands)

$4 \quad$ TIL Propagation and Tracking II

Thomas Weyrauch, University of Maryland, College Park (USA) 
5 Aerosol Extinction: Modeling and Measurement

Frank D. Eaton, Air Force Research Laboratory (USA)

6 Novel Methods and Designs

Stephen M. Hammel, Space and Naval Warfare Systems Center, San Diego (USA) 